\title{
Comparison of Hero 642 and $K 3$ rotary nickel-titanium files in curved canals of molars and a systematic review of the literature
}

\author{
HUA-XIONG CAI ${ }^{1}$, HUI-LING CHENG ${ }^{2}$, JIE-WEN SONG $^{3}$ and SU-YA CHEN ${ }^{1}$ \\ ${ }^{1}$ Department of Operative Dentistry and Endodontics, Guanghua School and Hospital of Stomatology and \\ Guangdong Provincial Key Laboratory of Stomatology, Sun Yat-sen University, Guangzhou, Guangdong 510055; \\ ${ }^{2}$ Department of Stomatology, The Second Affiliated Hospital, Sun Yat-sen University, Guangzhou, Guangdong 510120; \\ ${ }^{3}$ Department of Stomatology, Eighth People's Hospital of Guangzhou, Guangzhou, Guangdong 510060, P.R. China
}

Received January 8, 2014; Accepted June 4, 2014

DOI: $10.3892 / \mathrm{etm} .2014 .1853$

\begin{abstract}
The aim of the present study was to compare the root canal preparation ability of rotary nickel-titanium (NiTi) Hero 642 and $\mathrm{K} 3$ files in curved mandibular or maxillary molars. A total of 40 extracted mandibular molars with two separate mesial canals, an apical width of approximately size $\leq 15$ and a root canal curvature of $15-30^{\circ}$ were randomly divided into two groups and instrumented using Hero $642(n=20)$ or K3 files $(\mathrm{n}=20)$. Canal straightening, working length, transportation, cross-sectional area, minimum dentin thickness and the canal angle curvature degree were examined, and a systematic review of the literature was conducted. No statistically significant differences were observed between the two groups with regard to the mean degree of straightening, mean change in working length, mean transportation, amount of dentin removed or remaining minimum dentin thickness $(\mathrm{P}>0.05)$. The canal angle curvature decreased in the two groups postoperatively. The systematic review identified six studies, and overall the two files performed similarly in the majority of categories examined. Therefore, the rotary NiTi Hero 642 and K3 files demonstrated comparable shaping abilities and maintenance of working length.
\end{abstract}

\section{Introduction}

Rotary nickel-titanium (NiTi) instruments are favored over stainless steel hand files for root canal treatment due to the superior quality of canal preparation (1). Although NiTi systems have similar features, they differ in their cross-sectional and shank design. The design of the instruments, including the cutting angle, number of blades, tip design, conicity and

Correspondence to: Dr Hua-Xiong Cai, Department of Operative Dentistry and Endodontics, Guanghua School and Hospital of Stomatology and Guangdong Provincial Key Laboratory of Stomatology, Sun Yat-sen University, 56 Lingyuan Xi Road, Guangzhou, Guangdong 510055, P.R. China

E-mail: caihuaxiong@126.com

Key words: canal curvature, canal strengthening, Hero 642 files, $\mathrm{K} 3$ files, root canal preparation cross-section, directly influences the flexibility, cutting efficacy and torsional resistance of the instrument (2), as well as their performance in narrow or wider canals $(3,4)$.

Hero 642 rotary instruments (Micro-Mega, Besençon, France) are comprised of a NiTi alloy, and incorporate instruments with .06, .04 and .02 tapers (T) in sizes 20, 25 and 30, with additional $.02 \mathrm{~T}$ in sizes 35 and 40 . The graduated tapers initially prepare the coronal portion of the root canal; the final shape being created by merging the apical and coronal preparations (5). The Hero 642 file contacts the root canal wall dentin via blade contact, and has a triple helix cross-sectional design with three cutting edges with a positive rake cutting angle that provides a high cutting efficiency and is less prone to torsional fatigue.

The K3 file (SybronEndo, West Collins, CA, USA) contacts the root canal wall dentin via radial plane contact, and has a large cross-sectional area with a negative rake angle as the cutting angle, a flattened non-cutting tip and an asymmetrical constant tapered active file design with a variable helical flute and a variable core diameter (6). The proportion of the core diameter to the outside diameter is greatest at the tip and decreases uniformly towards the shank, resulting in greater flute depth and increased flexibility. The K3 instruments have non-cutting tips which minimize the risks of ledging, zipping, perforations and canal transportation, however, are more prone to torsional fatigue (6).

Numerous studies have compared NiTi instruments in extracted molars; however, the investigations are primarily limited to extracted teeth from Caucasian populations (7-11). The aim of the present study was to examine root canal preparations of Hero 642 and K3 rotary instruments in molars from southern Chinese individuals, and to perform a systematic review to summarize the observations of previous studies comparing Hero 642 and K3 files in order to obtain a more comprehensive understanding of the differences between the techniques.

\section{Materials and methods}

Specimen selection and preparation. Extracted first and second mandibular molars with intact crowns and fully-formed apices were collected from the Department of Stomatology of the Second Affiliated Hospital of Sun Yat-Sen University 
(Guangzhou, China). Soft tissues and hard deposits on the surface of the teeth were removed by scaling; the teeth were placed in 5\% sodium hypochlorite solution for $1 \mathrm{~h}$ to facilitate cleaning. The teeth were then stored in normal physiological saline until required. A total of 40 mandibular molars were selected based on the following criteria: Two separate mesial canals, apical width of approximately size $\leq 15$ (evaluated using files until size 15) and root canal curvature of $15-30^{\circ}$ (determined by radiographs). The teeth were randomly assigned to two groups of 20 teeth each (groups A and B) using a randomization table.

Conventional access cavities were formed, and the mesial canals were controlled for patency using a size $10 \mathrm{~K}$-file (Dentsply Maillefer, Ballaigues, Switzerland). Grooves were established in the walls of the middle section to allow the removal and exact repositioning of the complete tooth blocks or sectioned parts of the tooth. All the teeth were shortened to a length of $17 \pm 2 \mathrm{~mm}$ by trimming the occlusal surfaces. The root tips were sealed with a thin film of wax and access cavities with cotton pellets, and the teeth were embedded in clear epoxy resin (Fig. 1A). A modified Bramante muffle system $(12,13)$ was used to embed the teeth for root canal preparation (Fig. 1B and C). Following polymerization of the resin, the wax was removed and the apical foramen was exposed. To determine the working length, a size $10 \mathrm{~K}$-file was introduced into the canal until the tip was just visible at the apical foramen. The working length was calculated to be $1 \mathrm{~mm}$ short of this distance.

To determine the angle of curvature, standardized radiographs were captured prior to instrumentation with a size 10 $\mathrm{K}$-file in the canal (Fig. 1D), and following instrumentation with a size $30 \mathrm{~K}$-file in the canal. All X-ray imaging was performed by the same experienced radiographer using a consistent orientation of the specimens to ensure reproducibility. The radiographs were obtained in the buccolingual and the mesiodistal directions. The films were then digitized using a scanner (Canoscan Lide 25; Canon, Inc., Tokyo, Japan) and input into software (AutoVue SM Pro; Cimmetry Systems, Inc., Cambridge, MA, USA) for measurements.

The clinical and proximal angles of curvature were measured according to Schneider's method (14) (Fig. 2), and the true angle of curvature (TAC) was calculated using Samyn's formula (15) as follows:

$$
\operatorname{TAC}=\operatorname{Arc} \operatorname{Tan}\left[(\operatorname{TanC})^{2}+(\operatorname{TanP})^{2}\right]^{1 / 2}
$$

where $\mathrm{C}$ was the clinical angle and $\mathrm{P}$ was the proximal angle. The angle of curvature was calculated in the direction of greater curvature.

Canal instrumentation. Group A were assigned for preparation with Hero 642 instruments (Micro-Mega, Besençon, France), while group B were assigned with K3 instruments (SybronEndo, West Collins, CA, USA). Hero 642 and K3 files were used with a 16:1 gear reduction hand piece powered by a torque-controlled electric motor (TCM EndoIV; Nouvag AG, Goldach, Switzerland) at a speed of $300 \mathrm{rpm}$ using a crown-down technique.

The sequences of instrumentation are summarized in Table I. The sequence of Hero 642 was modified by omitting
Table I. Instrumentation sequences for Hero 642 and K3.

\begin{tabular}{lll}
$\begin{array}{l}\text { Instrumentation } \\
\text { system }\end{array}$ & $\begin{array}{c}\text { Sequence of } \\
\text { instruments }\end{array}$ & \multicolumn{1}{c}{ Steps } \\
\hline $\begin{array}{l}\text { Hero 642 } \\
\text { instruments }\end{array}$ & $\begin{array}{l}\text { Size 30 .06T file } \\
\text { Size 30.04T file } \\
\text { Size 25 } 206 \mathrm{~T} \text { file }\end{array}$ & $\begin{array}{l}\text { Preparing canals until } \\
\text { encountering resistance }\end{array}$ \\
& Size 25 .04T file & Preparing canals until \\
& Size 30 .04T file & reaching working length \\
K3 instruments & Size 25 10T file & Opening orifice \\
& Size 25 .08T file & \\
& Size 30 .06T file & Preparing canals until \\
& Size 30 .04T file & encountering resistance \\
& Size 25 .06T file & \\
& Size 25 .04T file & Preparing canals until \\
& Size 30 .04T file & reaching working length \\
& &
\end{tabular}

the .02T. First, size 30.06 and $.04 \mathrm{~T}$ files were used to enlarge the coronal third of the root canal. Next, a size $25.06 \mathrm{~T}$ file was used to prepare the coronal segment of the root canal, followed by a size $25.04 \mathrm{~T}$ file to smoothly reach the working length, with a size $30.04 \mathrm{~T}$ file as the master apical. The instruments were gently moved apically in a circumferential brushing motion until resistance was felt. No pecking motion or apical pressure was applied. The canal patency was examined with a size 8 $\mathrm{K}$-file in order to assure no dentin debris remained. The total number of times each set of instruments was used was 15. All instrumentations were performed by the same operator that was experienced in the use of Hero 642 and K3 instruments.

Assessment of canal preparation. In the two groups, the mesiobuccal canals were first instrumented in unsectioned teeth and the change in canal curvature was recorded. The distance from the coronal stop to the tip of the file was measured, and following calibration, the distance from the tip of the file to the radiographic apex was determined. The difference between the preoperative and postoperative measurements provided the alteration in the working length. All measurements were performed by an operator blinded to the experimental grouping.

Following the completion of mesiobuccal canal preparation, the tooth blocks were sectioned at a distance of 3 and $6 \mathrm{~mm}$ from the apex using a low-speed diamond saw (IsoMet Low Speed Saw; Buehler, Lake Bluff, IL, USA). The section at $3 \mathrm{~mm}$ from the apex was defined as the apical level and the section at $6 \mathrm{~mm}$ from the apex was defined as the middle level (Fig. 1E). The sections were scanned and stored as jpeg images. The blocks were reassembled in the muffle system, and the mesiolingual canals were instrumented using the same technique. The sections were again digitized, and the pre- and postoperative cross-sectional canal spaces were colored and superimposed manually using Photoshop CS3 (Adobe Systems, Inc., San Jose, CA, USA; Fig. 3). In the mesiolingual preparations, the preand postoperative cross-sectional areas were recorded using a computer program (AutoVue SM Pro). Sections of the teeth were evaluated for canal transportation, cross-sectional area and the minimum remaining dentin thickness. Canal transportation 
A

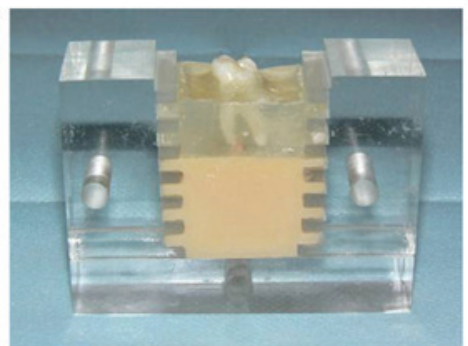

$\mathbf{C}$

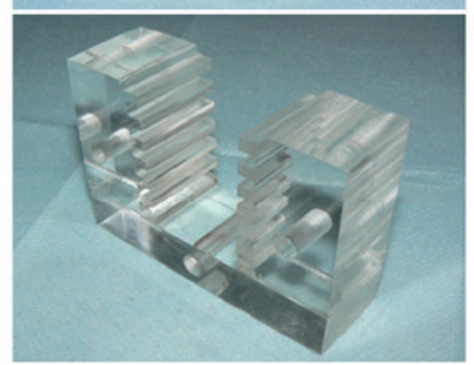

B

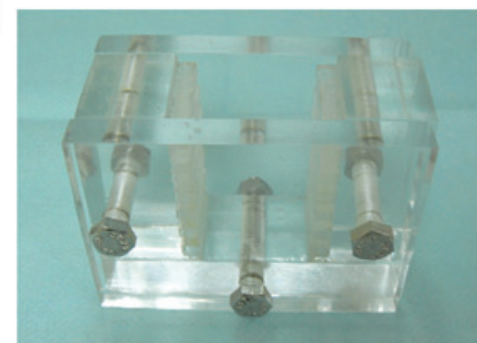

D

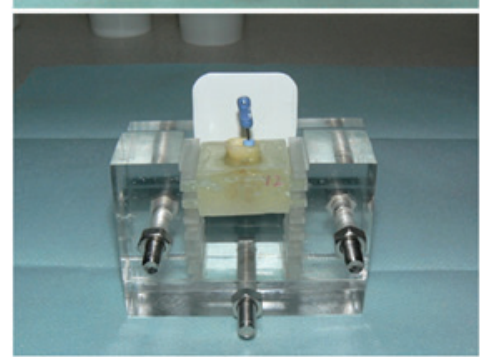

E

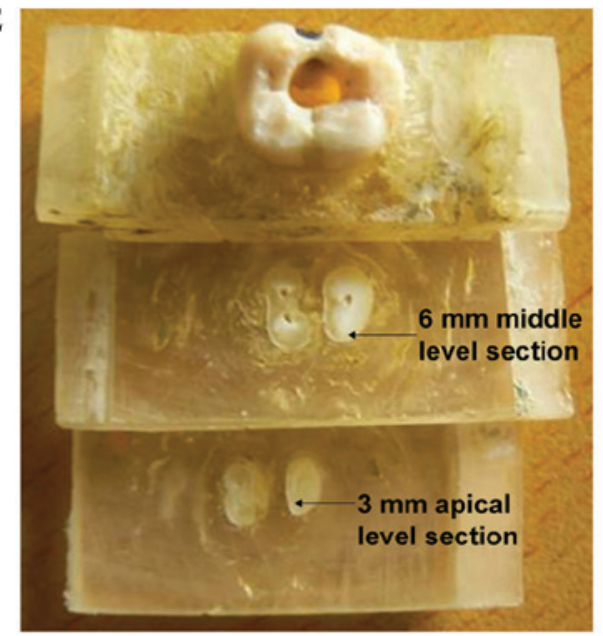

Figure 1. Representative images showing (A) a tooth embedded in clear epoxy resin; (B) the muffle block system; (C) the middle section of the muffle system revealing the grooves; and (D) the file in the canal. Radiographs were obtained in buccolingual and mesiodistal directions. X-ray films were placed behind the teeth for radiography. (E) Two observation levels were selected, one was $3 \mathrm{~mm}$ from the apex, defined as the 'apical level' and the other was $6 \mathrm{~mm}$ from the apex, defined as the 'middle level'.

A

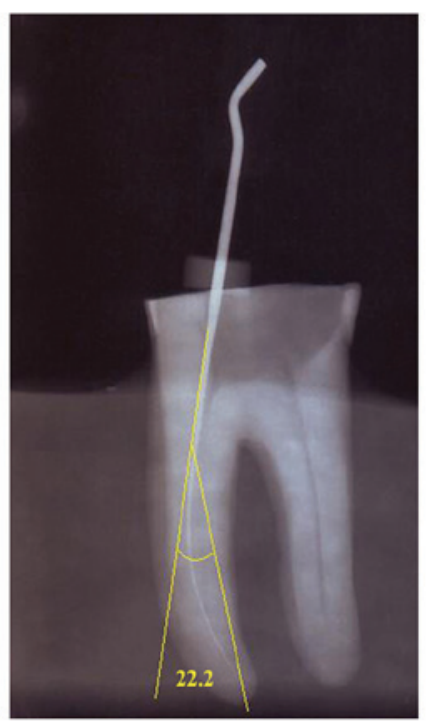

B

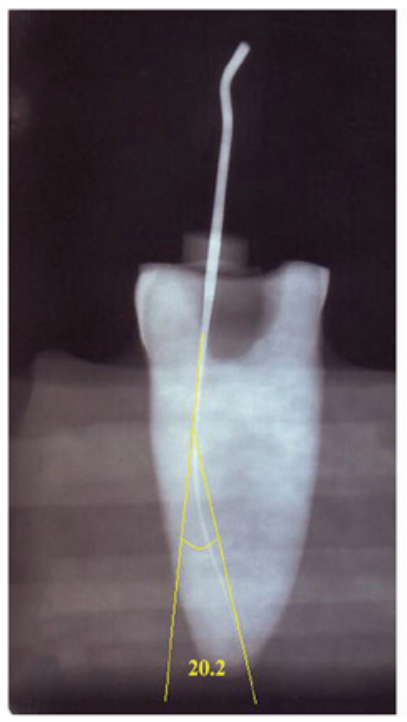

Figure 2. Measurement of the angle of curvature from the (A) mesiodistal and (B) buccolingual radiographic views.

A

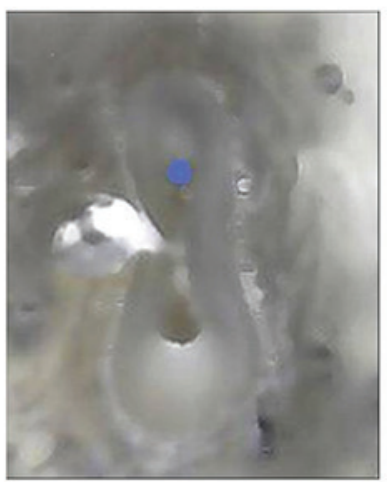

Before operation
B

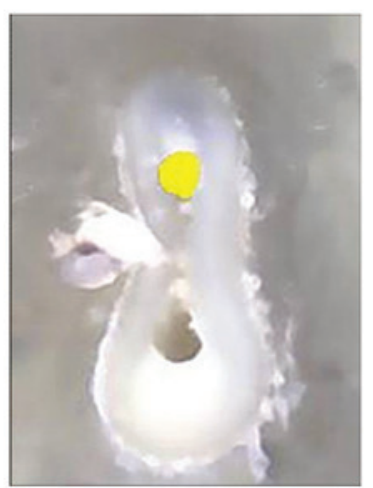

After operation
C

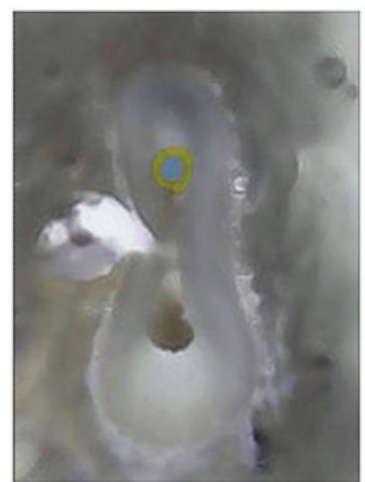

Superimposed

Figure 3. Differences between pre- and postoperative canal areas. (A) Preoperative (canal designated in blue); (B) postoperative (canal designated in yellow); (C) superimposed root cross-sections. The superimposed area was used to further calculate outcome measures. 


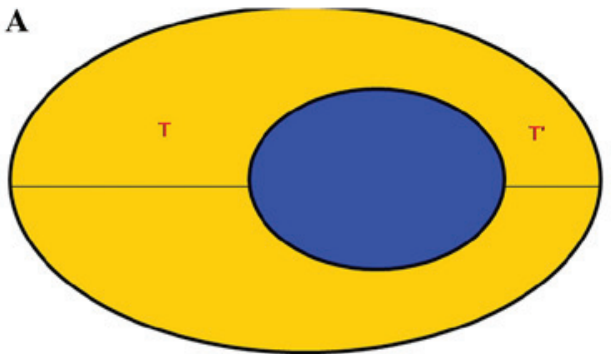

$$
\begin{aligned}
& \text { Net Transportation }=\mathbf{T}-\mathbf{T} \\
& \text { Blue }: \text { before operation }
\end{aligned}
$$$$
\text { Yellow : after operation }
$$

C

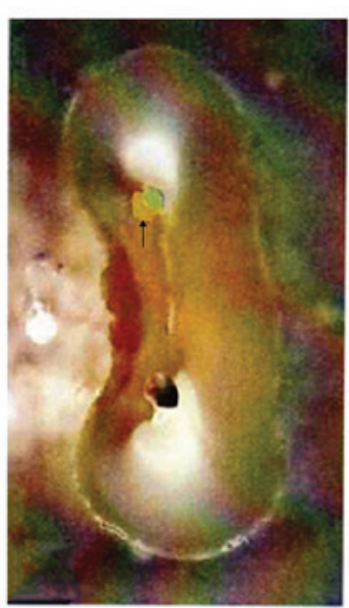

B

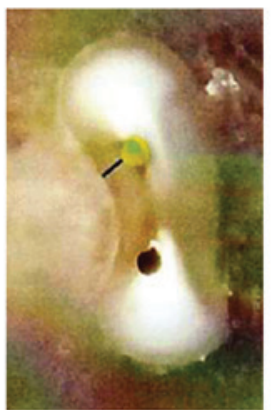

D

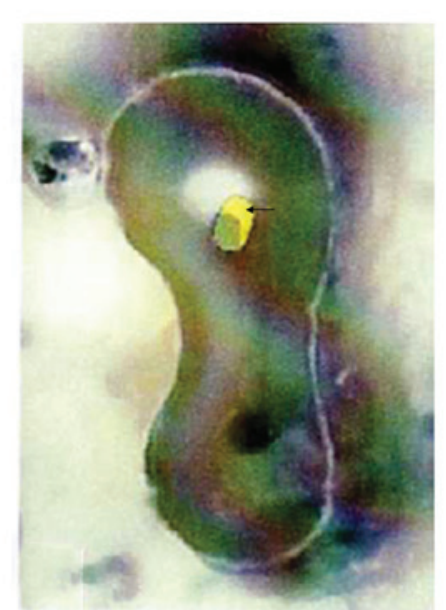

Figure 4. (A) Canal transportation measurements at the direction of maximum transportation (net transportation $\left.=\mathrm{T}-\mathrm{T}^{\prime}\right)$. $(\mathrm{B})$ Black line in the root cross-section indicates the remaining minimum dentin thickness following instrumentation. (C) Net transportation towards the inside of the curve (distal) at the middle level in the Hero 642 group. (D) Net transportation towards the outside of the curve (mesial) at the apical level in the Hero 642 group.

Table II. Pre- and postoperative root canal curvatures in the mesiobuccal instrumentation.

\begin{tabular}{lccc}
\hline & \multicolumn{2}{c}{ Angle of curvature $\left(^{\circ}\right)$} & \\
\cline { 2 - 3 } Group & Preoperative & Postoperative & P-value \\
\hline Hero 642 $(\mathrm{n}=20)$ & $19.7 \pm 6.2^{\mathrm{a}}$ & $16.2 \pm 6.5$ & 0.091 \\
K3 $(\mathrm{n}=20)$ & $21.2 \pm 6.9^{\mathrm{a}}$ & $18.7 \pm 6.1$ & 0.239 \\
\hline
\end{tabular}

Data are presented as the mean \pm standard deviation. ${ }^{\mathrm{a}} \mathrm{P}=0.473$, indicating no significant difference in the preoperative angle of curvature between the two groups.

was measured only in the direction of maximum transportation, using the method described by Bergmans et al (16), via the calculation of net transportation. This was defined as T-T', where $\mathrm{T}$ represented the difference in the maximum radius following root canal preparation and the radius prior to root canal preparation; $\mathrm{T}^{\prime}$ represented the difference in the minimum radius following root canal preparation and the radius prior to root canal preparation; and $\mathrm{T}-\mathrm{T}^{\prime}$ represented the deviation from the middle position of the root canal following preparation (Fig. 4A). The cross-sectional area of each section was measured and evaluated prior to and following canal preparation, with the difference indicating the amount of dentin removed at each level. The remaining dentin thickness was measured as the distance from the outer aspect of the canal to the outer aspect of the root in all directions, with the shortest distance considered the minimum remaining dentin thickness (Fig. 4B).

Canal straightening. Instrument systems were assessed for canal straightening on patients who were undergoing observations for root canal treatment in the Department of Endodontics of the Second Affiliated Hospital of Sun Yat-sen University (Guangzhou, China). Twenty canals were instrumented with the Hero 642 instruments and 20 canals with the K3 system, which were then evaluated for the degree of straightening. The canals were mesial canals of mandibular molars or mesiobuccal canals of maxillary molars. Canal preparation was performed according to the aforementioned technique to an apical size of 30 and $.04 \mathrm{~T}$. The pre- and postoperative radiographs were digitized, and the degree of canal straightening was calculated for the two groups. The study was approved by the Institutional Review Board of the Second Affiliated Hospital of the Sun Yat-sen University, and all the patients provided written informed consent.

Statistical analysis. SPSS 11.0 software (SPSS, Inc., Chicago, IL, USA) was used for the statistical analysis. All data regarding canal straightening, alterations in the working length, transportation, cross-sectional area and dentin thickness were analyzed using the Mann-Whitney $\mathrm{U}$ test, where $\mathrm{P}<0.05$ was considered to indicate a statistically significant difference. SPSS 11.0 soft- 
Table III. Canal straightening, change in working length and canal transportation in the mesiolingual instrumentation.

\begin{tabular}{|c|c|c|c|}
\hline Parameter & Hero $642(n=20)$ & K3 (n=20) & P-value \\
\hline Canal straightening $\left({ }^{\circ}\right)$ & $3.4 \pm 2.5$ & $2.6 \pm 1.9$ & 0.273 \\
\hline Change in working length (mm) & $0.151 \pm 0.106$ & $0.223 \pm 0.138$ & 0.076 \\
\hline \multicolumn{4}{|l|}{ Canal transportation (mm) } \\
\hline Middle level & $0.132 \pm 0.075$ & $0.141 \pm 0.098$ & 0.894 \\
\hline Apical level & $0.086 \pm 0.069$ & $0.088 \pm 0.044$ & 0.691 \\
\hline
\end{tabular}

Data are presented as the mean \pm standard deviation.

Table IV. Mean pre- and postoperative cross-sectional areas and amount of dentin removed in the mesiolingual instrumentation.

\begin{tabular}{|c|c|c|c|}
\hline Parameter & Hero $642(n=20)$ & $\mathrm{K} 3(\mathrm{n}=20)$ & P-value \\
\hline \multicolumn{4}{|c|}{ Cross-sectional area $\left(\mathrm{mm}^{2}\right)$} \\
\hline \multicolumn{4}{|l|}{ Middle level } \\
\hline Preoperative & $0.177 \pm 0.140$ & $0.131 \pm 0.075$ & 0.467 \\
\hline Postoperative & $0.296 \pm 0.124^{\mathrm{a}}$ & $0.254 \pm 0.075^{\mathrm{a}}$ & 0.121 \\
\hline \multicolumn{4}{|l|}{ Apical level } \\
\hline Preoperative & $0.076 \pm 0.062$ & $0.082 \pm 0.057$ & 0.887 \\
\hline Postoperative & $0.153 \pm 0.016^{\mathrm{a}}$ & $0.143 \pm 0.044^{\mathrm{a}}$ & 0.730 \\
\hline \multicolumn{4}{|c|}{ Dentin removed $\left(\mathrm{mm}^{2}\right)$} \\
\hline Middle level & $0.122 \pm 0.057$ & $0.125 \pm 0.081$ & 0.804 \\
\hline Apical level & $0.075 \pm 0.041$ & $0.063 \pm 0.031$ & 0.654 \\
\hline
\end{tabular}

Data are presented as the mean \pm standard deviation. ${ }^{a}$ Indicates a statistically significant difference between the pre- and postoperative values.

ware was used for the analysis (SPSS Inc, Chicago, IL, USA) was used for the statistical analyses.

Systematic review. A search of Medline, Cochrane, EMBASE and Google Scholar databases was performed on June 30, 2013 using combinations of the following keywords: Hero 642, K3, NiTi, rotary nickel-titanium file and root canal preparation. Studies were included in the review if they met the following criteria: i) Compared Hero 642 and K3 files with use in human teeth; ii) prospective comparative or randomized study; and iii) written in the English language. Studies were identified using this search strategy by two independent reviewers. Where there was uncertainty regarding eligibility, a third reviewer was consulted.

The following information was extracted from the studies that met the inclusion criteria: Name of the first author, year of publication, study design, number of subjects, type of subjects, outcome measures and the results of the comparison between Hero 642 and K3.

\section{Results}

Mesiobuccal canal instrumentation. Mean preoperative angles of curvature were $19.7^{\circ}$ in group A and $21.2^{\circ}$ in group B $(\mathrm{P}=0.473$; Table II). No statistically significant difference was identified between the preoperative and postoperative degrees of root canal curvature in the two groups (Table II). The mean degree of straightening was $3.4^{\circ}$ in group $\mathrm{A}$ and $2.6^{\circ}$ in group $\mathrm{B}(\mathrm{P}=0.273$; Table III). The mean change in working length was greater in group B compared with group A, however, the difference was not statistically significant $(\mathrm{P}=0.076$; Table III). No file breakage occurred in the groups and all the canals remained patent.

Mesiolingual canal instrumentation. In the two groups, the canals demonstrated a tendency towards inner transportation in the middle sections. With the Hero 642 system, 17 out of 18 canals were transported towards the inside of the curve (distal) in the middle $6 \mathrm{~mm}$ sections (Fig. 4C), and only one canal was transported towards the outside of the curve (mesial). With regard to the apical sections, nine out of 18 canals were transported towards the outside of the curve (mesial; Fig. 4D), eight canals were transported towards the inside of the curve (distal) and one canal remained centered.

With the K3 files, four canals out of 18 were transported towards the outside of the curve, while 14 canals were transported towards the inside of the curve at the middle level. At the apical level, nine canals out of 18 were transported towards the outside of the curve, eight canals were transported towards the inside and one canal remained centered. At the middle level, the mean transportation was $0.132 \mathrm{~mm}$ in group $\mathrm{A}$ and $0.141 \mathrm{~mm}$ in group $\mathrm{B}(\mathrm{P}=0.894$; Table III). 


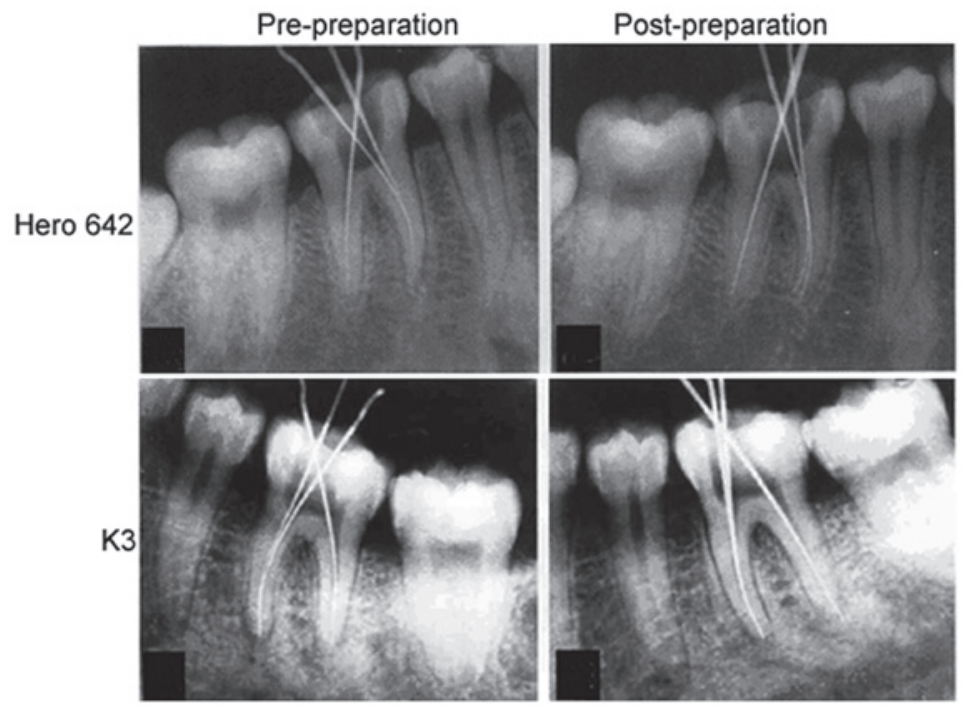

Figure 5. Representative radiographs of the patients treated with Hero 642 and K3 instruments.

Table V. Mean pre- and postoperative remaining minimum dentin thickness in the mesiolingual instrumentation.

\begin{tabular}{lccc}
\hline Parameter & Hero 642 $(\mathrm{n}=20)$ & $\mathrm{K} 3(\mathrm{n}=20)$ & P-value \\
\hline $\begin{array}{l}\text { Middle level } \\
\text { Preoperative }\end{array}$ & $0.997 \pm 0.202$ & $0.954 \pm 0.357$ & 0.235 \\
Postoperative & $0.821 \pm 0.255^{\mathrm{a}}$ & $0.737 \pm 0.383^{\mathrm{a}}$ & 0.215 \\
& & & \\
Apical level & & & \\
Preoperative & $0.845 \pm 0.225$ & $0.751 \pm 0.167$ & 0.255 \\
Postoperative & $0.777 \pm 0.221^{\mathrm{a}}$ & $0.685 \pm 0.177^{\mathrm{a}}$ & 0.344 \\
\hline
\end{tabular}

Data are presented as the mean \pm standard deviation. ${ }^{\text {andicates a }}$ statistically significant difference between the pre- and postoperative values.

Table VI. Angles of curvature prior to and following instrumentation.

\begin{tabular}{lccc}
\hline Group & Preoperative $\left({ }^{\circ}\right)$ & Postoperative $\left(^{\circ}\right)$ & P-value \\
\hline $\begin{array}{l}\text { Hero 642 } \\
(\mathrm{n}=20)\end{array}$ & $20.5 \pm 6.3$ & $16.1 \pm 6.2$ & 0.022 \\
$\begin{array}{l}\mathrm{K} 3 \\
(\mathrm{n}=20)\end{array}$ & $22.8 \pm 6.7$ & $19.3 \pm 6.5$ & 0.045 \\
\hline
\end{tabular}

In the apical sections, the difference in mean transportation between groups $\mathrm{A}$ and $\mathrm{B}$ was not statistically significant $(0.086$ vs. $0.088 \mathrm{~mm}$, respectively; $\mathrm{P}=0.691$; Table III).

Cross-sectional areas and the amount of dentin removed are shown in Table IV. The mean preoperative cross-sectional area was similar between groups A and B at the apical and middle levels. No statistically significant differences in the mean postoperative cross-sectional area were observed at the middle $(\mathrm{P}=0.121)$ or apical level $(\mathrm{P}=0.730)$. However, the difference between the mean pre- and postoperative cross-sectional areas was significant for groups A and B at the middle and apical levels. No statistically significant difference in the amount of dentin removed was observed between the two groups at the middle $(\mathrm{P}=0.804)$ or apical levels $(\mathrm{P}=0.654)$.

The difference between the mean pre- and postoperative dentin thickness was statistically significant in groups A and $\mathrm{B}$ at the middle level, but not significant at the apical level $(\mathrm{P}<0.05$; Table V). Postoperatively, no statistically significant difference in the remaining minimum dentin thickness was observed between the groups at the middle $(\mathrm{P}=0.215)$ or apical level $(\mathrm{P}=0.344)$.

Canal straightening. Representative radiographies of the patients treated with Hero 642 and K3 instruments are demonstrated in Fig. 5. No statistically significant difference in the preoperative angle of curvature was observed between the canals in the two groups $(\mathrm{P}>0.05)$. Postoperatively, the average angle of curvature was significantly decreased in the Hero 642 $(\mathrm{P}=0.022)$ and $\mathrm{K} 3$ groups $(\mathrm{P}=0.045$; Table $\mathrm{VI})$. The average degrees of canal straightening in the Hero 642 and $\mathrm{K} 3$ groups were $4.4 \pm 2.7$ and $3.4 \pm 3.5^{\circ}$, respectively $(\mathrm{P}=0.213)$.

Systematic review. A total of 197 studies were identified using the search criteria. Following the exclusion of non-relevant studies and those that did not meet the inclusion criteria, six studies were included in the review (17-22). The characteristics of the studies are shown in Table VII. Overall, Hero 642 and K3 files performed similarly in the categories examined. Notably, Prati et al (22) performed scanning electron microscopy to evaluate the ultrastructural morphology of root canal walls and identified that the K3 group had marked pulpal debris in the apical third when compared with the Hero 642 group. However, De-Deus et al (18) did not identify a statistically significant difference in the remaining pulp tissue between the Hero 642 and K3 groups when using routine microscopic histological examinations. Guelzow et al (20) reported that the working time for Hero 642 files was greater compared with the K3 files, however, the time required for changing the instruments of Hero 642 files was reduced in comparison. 
Table VII. Characteristics of the selected studies.

\begin{tabular}{|c|c|c|c|c|c|}
\hline $\begin{array}{l}\text { First author } \\
\text { (year) }\end{array}$ & $\begin{array}{l}\text { Study } \\
\text { design }\end{array}$ & Teeth & $\begin{array}{l}\text { Teeth } \\
(\mathrm{n})\end{array}$ & $\begin{array}{l}\text { Instruments } \\
\text { compared }\end{array}$ & $\begin{array}{c}\text { Outcome measures/results of the comparison } \\
\text { between Hero } 642 \text { and K3 }\end{array}$ \\
\hline $\begin{array}{l}\text { De-Deus G } \\
(2009)(16)\end{array}$ & ex vivo & $\begin{array}{l}\text { Mandibular } \\
\text { molars }\end{array}$ & 67 & $\begin{array}{l}\text { Hero } 642 \\
\text { K3 } \\
\text { ProTaper }\end{array}$ & Remaining pulp tissue: Hero $642=\mathrm{K} 3$ \\
\hline $\begin{array}{l}\text { Mohammadi Z } \\
\text { (2007) (19) }\end{array}$ & ex vivo & $\begin{array}{l}\text { Maxillary } \\
\text { central } \\
\text { incisor }\end{array}$ & 110 & $\begin{array}{l}\text { Hero } 642 \\
\text { K3 } \\
\text { Flex Master } \\
\text { Profile GT } \\
\text { RoCe } \\
\text { Control }\end{array}$ & Bacterial colonies: Hero $642=\mathrm{K} 3$ \\
\hline $\begin{array}{l}\text { de Carvalho } \\
\text { Maciel AC } \\
(2006)(15)\end{array}$ & ex vivo & $\begin{array}{l}\text { Single- } \\
\text { rooted } \\
\text { teeth }\end{array}$ & 100 & $\begin{array}{l}\text { Hero } 642 \\
\text { K3 } \\
\text { ProFile } \\
\text { ProTaper } \\
\text { Manual }\end{array}$ & $\begin{array}{l}\text { Amount of filling debris remaining } \\
\text { on the canal walls: Hero } 642=\mathrm{K} 3\end{array}$ \\
\hline $\begin{array}{l}\text { Guelzow A } \\
(2005)(18)\end{array}$ & ex vivo & $\begin{array}{l}\text { Mandibular } \\
\text { molars }\end{array}$ & 147 & $\begin{array}{l}\text { Hero } 642 \\
\text { K3 } \\
\text { ProTaper } \\
\text { RaCe } \\
\text { Flex Master } \\
\text { System GT } \\
\text { Manual }\end{array}$ & $\begin{array}{l}\text { Working time: Hero } 642>\mathrm{K} 3 \\
\text { Time for changing instruments: Hero } 642<\mathrm{K} 3 \\
\text { Working length: Hero } 642=\mathrm{K} 3 \\
\text { Straightening of curved root canals: Hero } 642=\mathrm{K} 3 \\
\text { Postoperative root canal diameter: Hero } 642=\mathrm{K} 3 \\
\text { Procedural incidents: Hero } 642=\mathrm{K} 3\end{array}$ \\
\hline $\begin{array}{l}\text { Prati C } \\
(2004)(20)\end{array}$ & in vitro & $\begin{array}{l}\text { Maxillary } \\
\text { incisors }\end{array}$ & 48 & $\begin{array}{l}\text { Hero } 642 \\
\text { K3 } \\
\text { RaCe } \\
\text { K-file } \\
\text { Manual }\end{array}$ & $\begin{array}{l}\text { Pulpal debris: Hero } 642<\mathrm{K} 3 \\
\text { Presence of smear layer: Hero } 642=\mathrm{K} 3 \\
\text { Inorganic debris: Hero } 642=\mathrm{K} 3 \\
\text { Surface profile: Hero } 642=\mathrm{K} 3\end{array}$ \\
\hline $\begin{array}{l}\text { González- } \\
\text { Rodríguez MP } \\
(2004)(17)\end{array}$ & in vitro & $\begin{array}{l}\text { Mandibular } \\
\text { molars }\end{array}$ & 34 & $\begin{array}{l}\text { Hero } 642 \\
\text { K3 } \\
\text { Profile }\end{array}$ & $\begin{array}{l}\text { Mean area of dentin removed: Hero } 642>\mathrm{K} 3 \\
\text { Mean initial area of the canal: Hero } 642=\mathrm{K} 3\end{array}$ \\
\hline Present study & ex vivo & $\begin{array}{l}\text { Mandibular } \\
\text { molars }\end{array}$ & 40 & $\begin{array}{l}\text { Hero } 642 \\
\text { K3 }\end{array}$ & $\begin{array}{l}\text { Canal straightening: Hero } 642=\mathrm{K} 3 \\
\text { Change in working length: Hero } 642=\mathrm{K} 3 \\
\text { Canal transportation: Hero } 642=\mathrm{K} 3 \\
\text { Amount of dentin removed: Hero } 642=\mathrm{K} 3 \\
\text { Remaining minimum dentin thickness: } \\
\text { Hero } 642=\mathrm{K} 3\end{array}$ \\
\hline
\end{tabular}

González-Rodríguez et al (19) reported that the mean area of dentin removal was greater with Hero 642 files than with K3 files.

\section{Discussion}

The present study found that Hero 642 and K3 instrument systems prepared root canals similarly with no file breakage. The root canals were prepared to an acceptable size and the original direction of the roots was preserved. The systematic review of studies comparing Hero 642 and K3 files found that the two files performed similarly in the majority of categories examined; however, differences were observed with regard to the working time, the time required for changing the instrument and the amount of dentin removed. The working lengths and canal straightening determined in the present study were similar to the results of previous studies; however, the amount of dentin removed differed from that reported by González-Rodríguez et al (19).

The results of the present study are in general accordance with other studies, affirming that NiTi files maintain the canal curvature $(9,20,23)$. Jodway and Hülsmann reported a mean straightening of $0.4^{\circ}$ for the K3 instrument (9), which is considerably less compared with the value reported in the present study, but highlights the minimal change in the curvature with NiTi files. Root canal straightening may reflect the file tip design and the natural tendency of NiTi files to straighten due to their elastic property (8). The K3 system has demonstrated advantages in preparing $\mathrm{S}$-shaped root canals, possibly due to the cross-sectional design and sequence encompassing a high number of instruments (8).

Previous studies have hypothesized that Hero 642 instruments do not prepare canals to a form with sufficient taper (5). Therefore, the $.02 \mathrm{~T}$ was omitted to allow larger and more 
tapered files to reach the apex, and also to enable direct comparison with the $\mathrm{K} 3$ instruments. This modification was favorable and the Hero 642 system performed similarly to that reported in other studies (24). With the two instruments there was a tendency towards inner transportation in the middle sections. Previous studies have reported canal transportation $(5,8,16,20,25)$; however, the clinical significance of small canal transportation has also been questioned (26).

No file breakage occurred in the present study, indicating that file breakage may be avoided if the files are carefully handled without the use of high pressure and timely irrigated. Previous studies have also reported the relative safety of these instruments during instrumentation $(9,27)$.

Hero 642 files have been reported to remove more dentin than K3 files (19), and K3 files are associated with greater remaining dentin thickness compared with a number of other instruments $(28,29)$. In the present study, no statistically significant difference was observed between the two instruments with regard to the amount of dentin removed. By contrast, González-Rodrguez et al (19) reported that Hero 642 files removed a greater mean area of dentin compared with K3 files. With respect to canal straightening, Hero 642 and $\mathrm{K} 3$ files were found to effectively decrease the angle of curvature, but there was no statistically significant difference in the average canal straightening.

The present study had several limitations. Firstly, the Hero 642 instrument sequence was modified from the manufacturer's recommendations. In addition, microscopic investigation of the canal walls to demonstrate debris removal was not performed. Furthermore, the teeth studied were restricted to an ethnic southern Chinese population and the sample size was relatively small. Therefore, generalizability of the results may be limited and further studies are required to determine their clinical utility.

In conclusion, the results of the present study and the systematic review indicate that the Hero 642 and K3 rotary NiTi instrument systems were comparable with respect to their centering ability, effect on the working length, amount of dentin removed and the minimum dentin thickness remaining following preparation. Although the two systems are of different designs, their results are concordant.

\section{References}

1. Schäfer E: Shaping ability of Hero 642 rotary nickel-titanium instruments and stainless steel hand K-Flexofiles in simulated curved root canals. Oral Surg Oral Med Oral Pathol Oral Radiol Endod 92: 215-220, 2001

2. Hülsmann M, Peters OA and Dummer PM: Mechanical preparation of root canals: shaping goals, techniques and means. Endod Topics 10: 30-76, 2005.

3. Markvart M, Darvann TA, Larsen P, et al: Micro-CT analyses of apical enlargement and molar root canal complexity. Int Endod J 45: 273-281, 2012.

4. Peters OA, Peters CI, Schönenberger K and Barbakow F: ProTaper rotary root canal preparation: effects of canal anatomy on final shape analysed by micro CT. Int Endod J 36: 86-92, 2003.

5. Thompson SA and Dummer PM: Shaping ability of Hero 642 rotary nickel-titanium instruments in simulated root canals: Part 1. Int Endod J 33: 248-254, 2000.

6. Gianluca G: The K3 rotary nickel titanium instrument system. Endod Topics 10: 179-182, 2005
7. Al-Omari MA, Aurich T and Wirtti S: Shaping canals with ProFiles and K3 instruments: does operator experience matter? Oral Surg Oral Med Oral Pathol Oral Radiol Endod 110: e50-e55, 2010.

8. Ersev H, Yılmaz B, Çiftçioğlu E and Özkarslı ŞF: A comparison of the shaping effects of 5 nickel-titanium rotary instruments in simulated S-shaped canals. Oral Surg Oral Med Oral Pathol Oral Radiol Endod 109: e86-e93, 2010.

9. Jodway B and Hülsmann M: A comparative study of root canal preparation with NiTi-TEE and K3 rotary Ni-Ti instruments. Int Endod J 39: 71-80, 2006.

10. Schäfer E, Erler M and Dammaschke T: Comparative study on the shaping ability and cleaning efficiency of rotary Mtwo instruments. Part 1. Shaping ability in simulated curved canals. Int Endod J 39: 196-202, 2006.

11. Schäfer E, Erler M and Dammaschke T: Comparative study on the shaping ability and cleaning efficiency of rotary Mtwo instruments. Part 2. Cleaning effectiveness and shaping ability in severely curved root canals of extracted teeth. Int Endod J 39: 203-212, 2006.

12. Bramante CM, Berbert A and Borges RP: A methodology for evaluation of root canal instrumentation. J Endod 13: 243-245, 1987.

13. Hülsmann M, Gambal A and Bahr R: An improved technique for the evaluation of root canal preparation. J Endod 25: 599-602, 1999.

14. Schneider SW: A comparison of canal preparations in straight and curved root canals. Oral Surg Oral Med Oral Pathol 32: 271-275, 1971.

15. Samyn JA, Nicholls JI and Steiner JC: Comparison of stainless steel and nickel-titanium instruments in molar root canal preparation. J Endod 22: 177-181, 1996.

16. Bergmans L, van Cleynenbreugel J, Beullens M, Wevers M, van Meerbeek B and Lambrechts P: Progressive versus constant tapered shaft design using NiTi rotary instruments. Int Endod J 36: 288-295, 2003.

17. de Carvalho Maciel AC and Zaccaro Scelza MF: Efficacy of automated versus hand instrumentation during root canal retreatment: an ex vivo study. Int Endod J 39: 779-784, 2006.

18. De-Deus G and Garcia-Filho P: Influence of the NiTi rotary system on the debridement quality of the root canal space. Oral Surg Oral Med Oral Pathol Oral Radiol Endod 108: e71-e76, 2009.

19. González-Rodríguez MP and Ferrer-Luque CM: A comparison of Profile, Hero 642, and K3 instrumentation systems in teeth using digital imaging analysis. Oral Surg Oral Med Oral Pathol Oral Radiol Endod 97: 112-115, 2004.

20. Guelzow A, Stamm O, Martus P and Kielbassa AM: Comparative study of six rotary nickel-titanium systems and hand instrumentation for root canal preparation. Int Endod J 38: 743-752, 2005.

21. Mohammadi Z: An ex vivo quantification of the apically extruded bacteria following use of nickel-titanium rotary instruments. J Clin Dent 18: 120-122, 2007.

22. Prati C, Foschi F, Nucci C, Montebugnoli L and Marchionni S: Appearance of the root canal walls after preparation with NiTi rotary instruments: a comparative SEM investigation. Clin Oral Investig 8: 102-110, 2004.

23. Schäfer E and Schlingemann R: Efficiency of rotary nickel-titanium K3 instruments compared with stainless steel hand K-Flexofile. Part 2. Cleaning effectiveness and shaping ability in severely curved root canals of extracted teeth. Int Endod J 36: 208-217, 2003.

24. Özer SY: Comparison of root canal transportation induced by three rotary systems with noncutting tips using computed tomography. Oral Surg Oral Med Oral Pathol Oral Radiol Endod 111: 244-250, 2011.

25. Garip Y and Gençoğlu N: Comparison of curved canals preparations using profile, GT and Hero 642 rotary files. J Oral Rehabil 33: 131-136, 2006.

26. Thompson SA and Dummer PM: Shaping ability of Hero 642 rotary nickel-titanium instruments in simulated root canals: Part 2. Int Endod J 33: 255-261, 2000.

27. Hülsmann M, Gressmann G and Schäfers F: A comparative study of root canal preparation using FlexMaster and Hero 642 rotary Ni-Ti instruments. Int Endod J 36: 358-366, 2003.

28. Shahriari S, Abedi H, Hashemi $M$ and Jalalzadeh SM: Comparison of removed dentin thickness with hand and rotary instruments. Iran Endod J 4: 69-73, 2009.

29. Weller PJ, Svec TA, Powers JM, Ludington Jr and Suchina JA: Remaining dentin thickness in the apical $4 \mathrm{~mm}$ following four cleaning and shaping techniques. J Endod 31: 464-467, 2005. 